\title{
RESEARCH PAPER \\ Growth and yield of rice cultivars sowed on different dates under tropical conditions
}

\author{
Gabriel Garcés-Varon'1, and Hermann Restrepo-Díaz ${ }^{2}$ \\ ${ }^{1}$ Seccional Saldaña, Federación Nacional de Arroceros (Fedearroz). Carrera 18 \# 23-112, Saldaña, \\ Colombia. \\ ${ }^{2}$ Departamento de Agronomía, Facultad de Ciencias Agrarias, Universidad Nacional de Colombia. Avenida \\ Carrera 30 \# 45-03, 111321 Bogotá, Colombia.
}

\begin{abstract}
G. Garces-Varon, and H. Restrepo-Díaz. 2015. Growth and yield of rice cultivars sowed on different dates under tropical conditions. Cien. Inv. Agr. 42(2):217-226. Rice plants are susceptible to low light or high temperature conditions during the reproductive and maturity stages. Two rice cultivars, Fedearroz 50 ('F50') and Fedearroz 733 ('F733'), were planted on three planting dates, January $1^{\text {st }}(\mathrm{PD} 1)$, February $15^{\text {th }}(\mathrm{PD} 2)$ and April $1^{\text {st }}(\mathrm{PD} 3)$, to expose them to different climatic conditions during the different stages of rice development. The experiment was a factorial arrangement. Of the various weather parameters, solar radiation fluctuated the most among the three different planting dates, with PD1 having the highest number of days with values $\geq 450 \mathrm{cal} \cdot \mathrm{cm}^{-2} \cdot \mathrm{d}^{-1}$. The yield components were influenced by the planting time. PD3 showed the lowest number of tillers per unit of area and the highest percentage of sterility spikelets. With respect to grain yield, PD1 and PD3 performed the best for both 'F50' and 'F733.' On the other hand, the optimum leaf area index (7) was reached at approximately 85-90 days for both cultivars for all three different planting dates. Similarly, solar radiation had a high correlation with the biomass production (dry matter) and leaf area index. In conclusion, the rice planting date should be adjusted so that the reproductive stage and grain filling do not coincide mainly with periods of low solar radiation $\left(\leq 430 \mathrm{cal} \cdot \mathrm{cm}^{-2} \cdot \mathrm{d}^{-1}\right)$ in tropical conditions.
\end{abstract}

Key words: Grain yield, leaf area index, planting date, rice, solar radiation, tillers, Unfilled Spikelet percentage.

\section{Introduction}

Rice is one of the main crops in Colombia, reaching a production of 2,283,981 tons over a total area of 445,414 ha in 2010 (DANE-Fedearroz, 2012). In general, the productivity of this crop can be influenced by environmental conditions such as

Received August 14, 2014. Accepted May 12, 2015. Corresponding author: hrestrepod@unal.edu.co solar radiation, temperature and water availability during growth and development (Fageria, 2007). Therefore, a good grain yield depends partially on the ability of the crop to intercept photosynthetically active radiation (PAR) (Ahmad et al., 2009). Similarly, the intercepted radiation is strongly affected by the leaf area index (LAI), which, in turn, is influenced by the genotype, planting density, crop nutrition and amount of solar radiation (Muchow and Carberry, 1989; Ahmad et al., 2009). 
Furthermore, some commercial cultivars of rice used in Colombia have shown wide changes in grain yields throughout different months of the year, mainly due to the high susceptibility to stressful climatic conditions such as low levels of solar radiation (Castilla et al., 2010). In addition, a $20-50 \%$ decrease in solar radiation can reduce the grain yield by approximately $40 \%$ in certain periods of the year in the rice-producing areas in Colombia (Restrepo and Garces, 2013).

High grain yields in cereals are the result of an increase in the availability of the assimilate supply (source) to achieve a grain setting and filling accompanied by an increase in the capacity of the sink (Tsimba et al., 2013). Consequently, a key factor influencing the rice grain weight is an adequate supply of assimilates during the maturity phase because source-sink relationships can be affected by environmental conditions and crop management techniques (Fageria, 2007; Khalifa, 2009). In general, several authors have reported that low radiation or high temperatures during the reproductive or maturity phase can negatively affect the capacity of the assimilate supply (photosynthesis), diminishing the size of the sink (number of filled spikelets) in rice plants (Fageria, 2007; Srivastava, 2011; Restrepo-Díaz and Garces-Varon, 2013; Sanchez-Reinoso et al., 2014).

The choice of planting date starts to play an important role in agronomic strategies for increasing or maintaining the crop yield under unfavorable environmental conditions during critical crop phenological stages. The dates of planting provide different growth conditions such as temperature, precipitation or solar radiation levels throughout the crop cycle (Tsimba et al., 2013). Different studies have shown that the planting date can affect the growth and yield parameters of rice crops such as the plant height, source-sink relationships, LAI, crop growth rate (CGR), net assimilation rate (NAR), number of panicles per square meter and number of filled spikelets (Ahmad et al., 2009; Khalifa, 2009).
For this reason, the objective of this study was to evaluate how the interaction between the planting date and the environmental conditions present during the growth cycle of the crop affects the accumulation of biomass, grain yield and yield components of two Colombian rice cultivars (Fedearroz 50 ['F50'] and Fedearroz 733 ['F733']). In this sense, 'F733' rice plants have been identified as a genotype with a certain degree of tolerance to adverse climatic variations such as high temperatures or low luminosity, while 'F50' plants have registered more unstable behavior under such variations (Restrepo and Garces, 2013; RestrepoDíaz and Garces-Varon, 2013).

\section{Materials and methods}

\section{General growth conditions}

The experiment was performed under field conditions during the period from January to August 2012 in the Research Center "Las Lagunas" Fedearroz - National Rice Fund in Saldaña (3 ${ }^{\circ} 54^{\prime} 47.45^{\prime}$ ” N, 7459'8.47” W), Colombia. Likewise, plants were established in experimental plots of the following dimensions: $7 \times 6 \mathrm{~m}\left(42 \mathrm{~m}^{2}\right)$. The planting system was broadcast seeding with uncovered seeds at a density of $180 \mathrm{~kg}$ of seeds per hectare. All of the crop management practices such as fertilization, weeds, arthropods and disease management were the same for the three planting dates, following the technical recommendations of the National Federation of Rice Growers (Fedearroz, 2012). The amounts of macronutrients were: $220 \mathrm{~kg} \mathrm{ha}^{-1}$ of $\mathrm{N}, 46 \mathrm{~kg} \mathrm{ha}^{-1}$ of $\mathrm{P}_{2} \mathrm{O}_{5}$ and $105 \mathrm{~kg} \mathrm{ha}^{-1}$ of $\mathrm{K}_{2} \mathrm{O}$. The soil moisture regime ranged from saturation to a low water layer on the soil surface. Environmental parameters such as solar radiation and maximum and minimum temperatures were recorded daily using an automatic weather station (Davis, NSW, AUS) during the experiment. Additionally, the total crop cycle was divided into three growth phases to analyze the influence of climatic factors on the crop growth: vegetative phase (0-45 days after germination (dag)), reproductive phase (46-78 dag) 
and maturity phase (78-115 dag). In general, the estimation of the duration of each growth stage was obtained by checking the morphological changes in the field for each planting date.

The weather conditions were recorded during the experiment. Table 1 shows the average and cumulative solar radiation and the temperature (maximum and minimum) for each growth stage under each planting date.

\section{Treatments}

Two rice cultivars ('F50' and 'F733') were sown on three different dates during the experiment. The planting dates were the following: i) Planting date 1 (PD1): January 1 1 ${ }^{\text {st }}, 2012$; ii) Planting date 2 (PD 2): February $15^{\text {th }}, 2012$, and iii) Planting date 3 (PD 3): April 2 $2^{\text {nd }}, 2012$. The above planting dates were chosen to obtain different environmental conditions (mainly solar radiation) during the crop cycle because the majority of rice areas are sown between January and May of each year in Colombia.

\section{Dry matter and leaf area index}

The dry matter and leaf area index (LAI) were measured every 14 days starting at 18 dag. All aerial tissues of the plants were collected in an area of $0.5 \times 0.5 \mathrm{~m}$ from each plot. Then, the fresh plant tissues were dried for 3 days at $60{ }^{\circ} \mathrm{C}$ in a stove to obtain the total dry matter (TPDW).

The LAI was measured with a plant canopy analyzer (LAI 2200, Li-Cor, Lincoln, NE, USA). The LAI value was obtained by the average of five measurements in each experimental plot. With the values of TPDW and LAI, the following growth rates were calculated according to the procedure suggested by Hunt (1978):

- Leaf area duration (LAD) (days) (Equation 1):

$$
L A D=\left[\frac{L A I_{1}+L A I_{2}}{2}\right]\left(T_{2}-T_{1}\right)
$$

where $\mathrm{LAI}_{1}$ and $\mathrm{LAI}_{2}$ are the leaf area indices at times $T_{1}$ and $T_{2}$, respectively.

Table 1. Weather conditions (Solar radiation and temperature) during the vegetative, reproductive and maturity stages of three different planting dates for 'F50' and 'F733' in the experimental period.

\begin{tabular}{|c|c|c|c|c|c|c|}
\hline \multirow[b]{2}{*}{ Solar radiation } & \multicolumn{2}{|c|}{ Planting date 1} & \multicolumn{2}{|c|}{ Planting date 2} & \multicolumn{2}{|c|}{ Planting date 3} \\
\hline & $\begin{array}{l}\text { Cumulative } \\
\left(\mathrm{cal} \mathrm{cm}^{-2}\right)\end{array}$ & $\begin{array}{c}\text { Average } \\
(\text { cal cm } \\
\left.\mathrm{d}^{-1}\right)\end{array}$ & $\begin{array}{l}\text { Cumulative } \\
\left(\mathrm{cal} \mathrm{cm}^{-2}\right)\end{array}$ & $\begin{array}{c}\text { Average } \\
(\text { cal cm } \\
\left.\mathrm{d}^{-1}\right)\end{array}$ & $\begin{array}{l}\text { Cumulative } \\
\left(\mathrm{cal} \mathrm{cm}^{-2}\right)\end{array}$ & $\begin{array}{c}\text { Average } \\
(\text { cal cm-2 } \\
\left.\mathrm{d}^{-1}\right)\end{array}$ \\
\hline \multicolumn{7}{|l|}{ Stage } \\
\hline Vegetative & 21622 & 470.1 & 20782 & 451.8 & 19267 & 418.8 \\
\hline Reproductive & 14286 & 432.9 & 13625 & 412.9 & 13535 & 410.2 \\
\hline Maturity & 16492 & 445.7 & 15583 & 421.2 & 16266 & 439.6 \\
\hline Total Culture Cycle & 52401 & 451.9 & 49991 & 430.8 & 49069 & 423.0 \\
\hline Temperature $\left({ }^{\circ} \mathrm{C}\right)$ & Maximum & Minimum & Maximum & Minimum & Maximum & Minimum \\
\hline \multicolumn{7}{|l|}{ Stage } \\
\hline Vegetative & 25.1 & 21.8 & 25.2 & 20.9 & 25.2 & 20.9 \\
\hline Reproductive & 24.1 & 20.9 & 25.2 & 20.9 & 25.0 & 21.8 \\
\hline Maturity & 25.2 & 20.9 & 24.9 & 21.8 & 25.7 & 20.9 \\
\hline
\end{tabular}


- Crop growth rate (CGR) $\left(\mathrm{g} \cdot \mathrm{m}^{-2} \cdot \mathrm{d}-{ }^{-1}\right)$ (Equation 2):

$$
C G R=\frac{\left(P_{2}-P_{1}\right)}{\left(T_{2}-T_{1}\right)}
$$

where $\mathrm{P}_{1}$ and $\mathrm{P}_{2}$ are the TPDW harvested at times $\mathrm{T}_{1}$ and $\mathrm{T}_{2}$, respectively.

- Net assimilation rate (NAR) $\left(\mathrm{g} \cdot \mathrm{m}^{-2} \cdot \mathrm{d}^{-1}\right)$ (Equation 3):

$$
N A R=\frac{T D M}{L A D}
$$

where TDM and LAD are the total dry matter and leaf area duration, respectively.

\section{Grain yield}

The grain yield evaluation was obtained by collecting rice grains in an area of $4 \mathrm{~m}^{2}$ in the approximate center of each experimental plot at $120 \mathrm{dag}$. The yield paddy was approximately calculated with a grain moisture content of $14 \%$. The grain yield was calculated with the following formula (Equation 4):

$$
K g h a^{-1}=\left[\frac{\mathrm{kg}}{\text { plot per } 4 \mathrm{~m}^{2}}\right] \times 10000
$$

Interception of photosynthetic active radiation (IPAR) and radiation use efficiency (RUE)

The fraction of intercepted radiation (Fi) was obtained by the method used by Ahmad et al. (2009) with the following formula (Equation 5):

$$
F_{i}=1-\exp { }^{(-k * I A F)}
$$

where $\mathrm{K}$ is an extinction coefficient for a total solar radiation of 0.63 for rice (Ritchie et al., 1998). The IPAR amount was estimated by multiplying the values of Fi with the daily PAR during each planting date. The daily PAR values were obtained as $50 \%$ of the total solar radiation values. Finally, RUE was estimated by the ratio of TPDW and the cumulative IPAR for each plot (Ahmad et al., 2009).

\section{Statistical analysis}

A factorial design with two factors (rice cultivars vs. planting dates) with four blocks was established, and a Tukey's test was performed when significant differences between the treatments were observed. All percentages were transformed using the arcsine transformation prior to the analysis. The statistical analysis was performed using the program Statistix (Analytical Software, Tallahassee, FL, USA). Prior to the statistical analysis, the data were subjected to a normal probability test (Shapiro-Wilk test) to confirm whether the data exhibited normal behavior. Moreover, a statistical analysis of the correlation between the climate parameters, TPDW and LAI, was performed by R open source software (version 2.15.0). Additionally, an elasticity test was conducted to quantify how the variation in the values of a climate parameter affected the dry matter and LAI. The adjustment of the dry matter curves and the leaf area index was performed using Curve Expert computer software.

\section{Results \\ Climate data}

Table 1 shows the accumulated solar energy during each growth phase for the three different planting dates as well as the average daily solar energy per phase. By analyzing this table, differences in the levels of solar energy received per phase of growth during the different planting dates could be observed. In general, values of 400 $\mathrm{cal} \cdot \mathrm{cm}^{-2} \cdot \mathrm{d}^{-1}$ (minimum level of solar radiation to achieve acceptable yield according to Yoshida, 1981) were observed in the three different planting dates during the experiment. However, PD1 showed the highest cumulative and average values of radiation compared with PD 2 and 3. When analyzing the different phenological phases, especially the maturity stage, planting date 1 had an average value of $445.7 \mathrm{cal} \cdot \mathrm{cm}^{-2} \cdot \mathrm{d}^{-1}$ compared with 421.2 and $439.6 \mathrm{cal} \cdot \mathrm{cm}^{-2} \cdot \mathrm{d}^{-1}$ for dates 2 and 
3 , respectively. With regard to the maximum and minimum temperatures during the experiment, they were close to the optimum range (approximately $25^{\circ} \mathrm{C}$ ) (Yoshida, 1981; Sanchez-Reinoso et al., 2014).

\section{Dry matter accumulation}

An analysis of the area under the curve was developed to statistically compare the dry matter accumulation of each variety caused by the three different planting dates evaluated (Figure 1). This analysis showed that the dry matter accumulation in the vegetative phase was lower in PD 1 with regard to the other dates in the 'F50' rice plants. In the reproductive phase, the lowest gain in matter occurred in PD 3. In the maturity stage, no difference between the total biomass and the three different planting dates (Figure 1A) was observed. For the 'F733' plants, patterns similar to those obtained in the 'F50' plants during the vegetative stage were observed (Figure 1B). Differences among the planting dates were not found in the reproductive phase. However, PD1 had the highest dry weight accumulation during the maturity stage. In this sense, the gain in dry matter in the 'F733' plants of date 1 was 62.7 and $72.2 \%$ higher compared with planting dates 2 and 3 , respectively.

\section{Growth rates}

The LAI of a community of plants corresponds to its leaf surface with respect to the ground area occupied by the foliage. When analyzing the maximum LAI reached, PD1 was observed to have the lowest maximum LAI compared with PD2 and 3 (6.39 vs. 7.23 and 7.06, respectively). The differences in the LAI between varieties and the interactions between the cultivar and planting date were not significant (Table 2). With respect to the accumulated LAD, PD 1 also had the lowest value. Differences in the accumulated LAD between varieties were also observed; the 'F733'

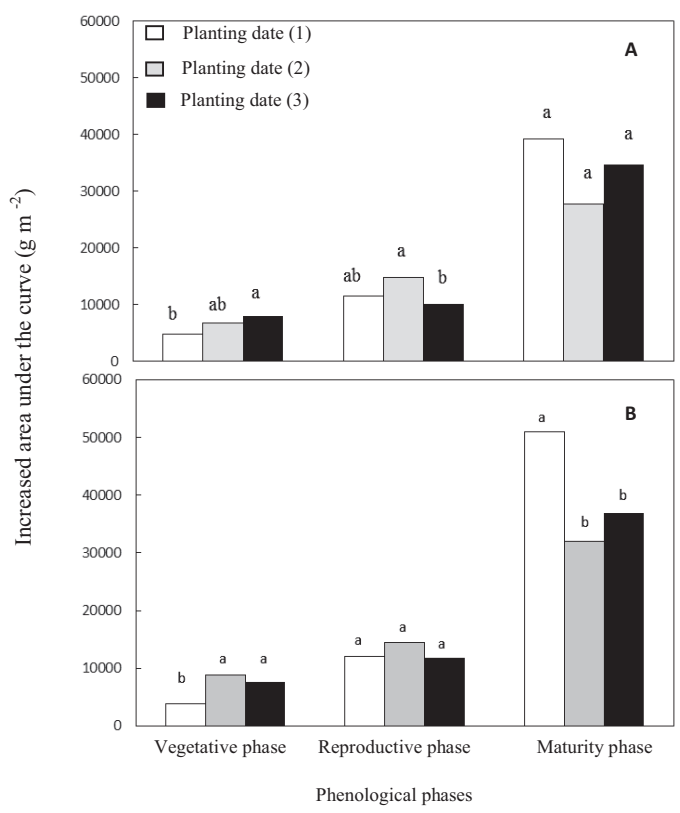

Figure 1. Analysis of the increased area under the curve of the dry matter accumulation per phenological phase of growth of two rice cultivars (Fedearroz 50 (A) and Fedearroz 733 (B)) during three planting dates (Planting date 1: January $1^{\text {st }}, 2012$; Planting date 2: February $15^{\text {th }}$, 2012; Planting date 3: April 1 1 ${ }^{\text {st }}, 2012$ ). Means with different letters represent statistically significant differences according to Tukey's test $(\mathrm{P} \leq 0.05)$.

plants performed better than the 'F50' plants. The average CGR only showed differences between the cultivars. Similar to the accumulated LAD, the 'F50' plants presented a lower CGR. Finally, the NAR was also affected either by the planting date or the cultivar used in the experiment. PD 1 showed a greater NAR despite having a lower value in variables such as LAI and accumulated LAD. Furthermore, the 'F733' plants continued to show a better growth rate throughout the experiment because the NAR was also higher in this cultivar.

\section{Yield components and grain yield}

Differences were found in the yield components only for the different planting dates. In general, the sowing dates did not affect the number of tillers per square meter (Figure 2A). However, 
Table 2. Influence of planting date and cultivar on the maximum leaf area index (LAI), average crop growth rate (CGR), accumulated leaf area duration (LAD) and net assimilation rate in two cultivars of rice ('F50' vs. 'F733').

\begin{tabular}{ccccc}
\hline & $\begin{array}{c}\text { LAI } \\
\text { Maximum }\end{array}$ & $\begin{array}{c}\text { CGR mean } \\
\left(\mathrm{g} \mathrm{m}^{-2} \cdot \mathrm{d}^{-1}\right)\end{array}$ & $\begin{array}{c}\text { LAD } \\
\text { accumulate }\end{array}$ & $\begin{array}{c}\mathrm{NAR} \\
\left(\mathrm{g} \mathrm{m}^{-2} \mathrm{~d}^{-1}\right)\end{array}$ \\
\hline Planting Date (PD) & & & & \\
1 & $6.39 \mathrm{a}^{1}$ & $25.27 \mathrm{a}$ & $351.78 \mathrm{a}$ & $4.75 \mathrm{a}$ \\
2 & $7.23 \mathrm{~b}$ & $21.33 \mathrm{a}$ & $427.48 \mathrm{~b}$ & $3.33 \mathrm{~b}$ \\
3 & $7.06 \mathrm{~b}$ & $22.15 \mathrm{a}$ & $467.07 \mathrm{c}$ & $3.17 \mathrm{~b}$ \\
Significance & $* * * 2$ & $\mathrm{~ns}$ & $* * *$ & $* * *$ \\
'F50' & $6.80 \mathrm{a}$ & $19.67 \mathrm{a}$ & $406.25 \mathrm{a}$ & $3.57 \mathrm{a}$ \\
'F733' & $6.98 \mathrm{a}$ & $26.17 \mathrm{~b}$ & $424.64 \mathrm{~b}$ & $3.93 \mathrm{~b}$ \\
Significance & $\mathrm{ns}$ & $*$ & $*$ & $*$ \\
PD $\times$ Cultivar & $\mathrm{ns}$ & $\mathrm{ns}$ & $\mathrm{ns}$ & $\mathrm{ns}$ \\
$\mathrm{CV}$ (\%) & 6.56 & 30.47 & 4.76 & 10.89 \\
\hline
\end{tabular}

${ }^{1}$ Means with different letters represent statistically significant differences according to Tukey's test $(\mathrm{P} \leq 0.05)$.

${ }^{2}$ ANOVA: *,**, and *** represent significant differences at the $0.05,0.01$ and 0.001 probability levels, respectively.

Ns: not significant at 0.05 .

${ }^{3} \mathrm{CV}=$ Coefficient of Variation.

the number of panicles per area unit and the percentage of empty spikelets were influenced by the planting date (Figure 2B and C). On the other hand, we observed significant differences in grain yield in the interaction between genotype and planting dates (Figure 3). The best yields were obtained during PD 1 (January $1^{\text {st }}, 2010$ ) with the two cultivars used in this study ('F50' and 'F733'), which exceeded the 7.5 tons per hectare. Additionally, similar trends in the rice plants planted on PD 3 (April 2 $2^{\text {nd }}, 2010$ ) were observed; both cultivars produced a yield of 7 tons. Finally, PD2 (March 15 ${ }^{\text {th }}, 2012$ ) had the lowest grain yield ( $\sim 6.5$ tons) in both cultivars.

\section{Influence of climatic factors on the growth variables}

The correlation analysis between the climatic factors and the growth variables is summarized in Table 3. The solar radiation and temperature were highly correlated with the biomass production (dry matter) and LAI. In contrast, the relative humidity did not show any correlation with those growth variables. Finally, the CGR showed no highly significant correlation $(\geq 0.75)$ with any of the climate variables recorded in the study.

An elasticity analysis was developed to quantify how changes in the temperature and solar radiation variables affect the biomass values and LAI (Table 4). In general, this elasticity analysis says that one unit of variation in the solar values causes a change in ratio of 2.191 for the biomass values and 1.429 for the LAI values. The elasticity model showed a high statistical significance $(\mathrm{P} \leq 0.001)$ for those variables. However, differences in CGR were not observed.

\section{IPAR and RUE}

Significant differences were only found on IPAR between sowing dates (Table 5). PD1 showed the highest IPAR $\left(1068.11 \mathrm{MJ} \cdot \mathrm{m}^{-2}\right)$ compared with PD2 $\left(1025.99 \mathrm{MJ} \cdot \mathrm{m}^{-2}\right)$ and PD3 (993.90 $\left.\mathrm{MJ} \cdot \mathrm{m}^{-2}\right)$. In contrast, significances were only obtained on the RUE between cultivars, with the 'F733' rice plants being more efficient than the 'F50'. 
Table 3. Correlation analysis between weather factors and growth variables in rice plants.

\begin{tabular}{lcccc}
\hline $\begin{array}{l}\text { Environmental } \\
\text { Factor } / \\
\text { Variable }\end{array}$ & $\begin{array}{c}\text { Cumulative } \\
\text { solar radiation }\end{array}$ & $\begin{array}{c}\text { Cumulative } \\
\text { maximum } \\
\text { temperature }\end{array}$ & $\begin{array}{c}\text { Cumulative } \\
\text { minimum } \\
\text { temperature }\end{array}$ & $\begin{array}{c}\text { Average } \\
\text { relative } \\
\text { humidity }\end{array}$ \\
\hline $\begin{array}{l}\text { Biomass } \\
\begin{array}{l}\text { Leaf area } \\
\text { index - LAI }\end{array}\end{array}$ & 0.959 & 0.959 & 0.959 & 0.219 \\
$\begin{array}{l}\text { Crop growth } \\
\text { rate-CGR }\end{array}$ & 0.864 & 0.873 & 0.891 & 0.001 \\
\hline
\end{tabular}

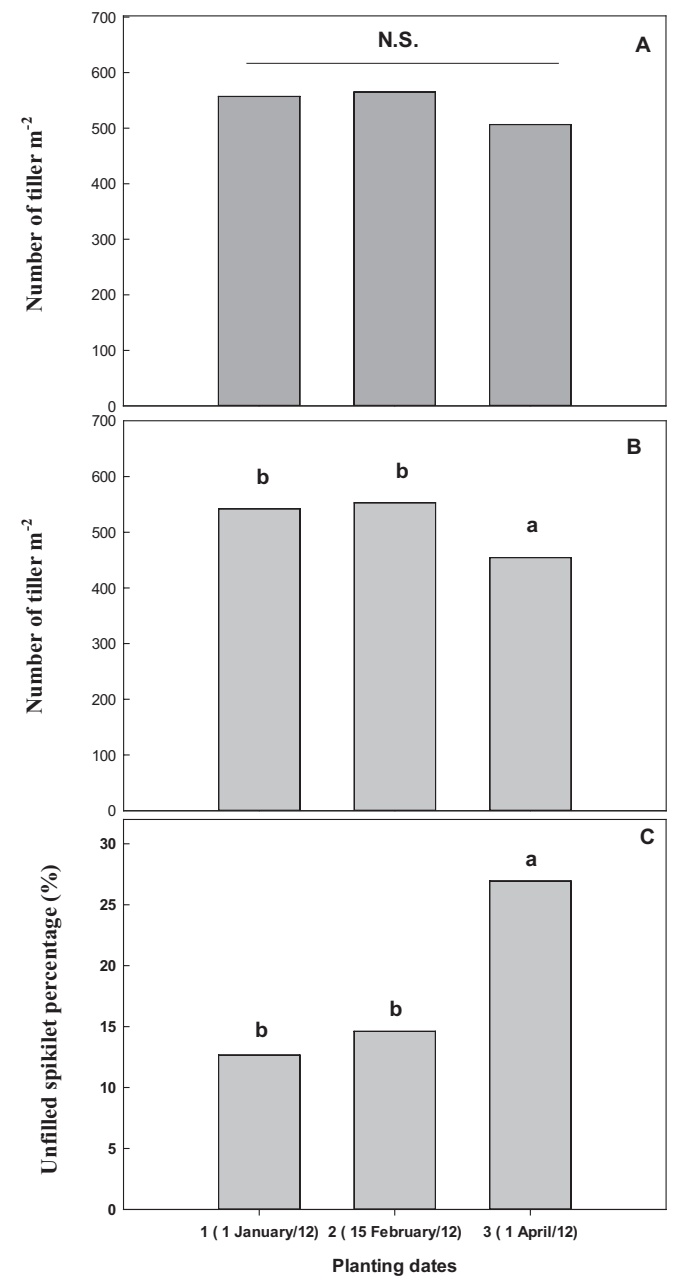

Figure 2. Effect of three planting dates (Planting date 1: January $1^{\text {st }}, 2012$; Planting date 2: February $15^{\text {th }}, 2012$; and Planting date 3: April $\left.1^{\text {st }}, 2012\right)$ on the number of tillers/ $\mathrm{m}^{2}(\mathrm{~A})$, the number of panicles $/ \mathrm{m}^{2}(\mathrm{~B})$ and the percentage of unfilled spikelets (C). Means with different letters represent statistically significant differences according to Tukey's test $(\mathrm{P} \leq 0.05)$. N.S.: not significant.

\section{Discussion}

In terms of the climatic values presented during the experiment, higher solar radiation values were recorded for PD1 (Table 1). In this sense, Yoshida (1981) reported that the appropriate solar energy values for each of the three growth stages of rice crops are $300-400 \mathrm{cal} \cdot \mathrm{cm}^{-2} \cdot \mathrm{d}^{-1}$ for the vegetative phase and $400-500 \mathrm{cal} \cdot \mathrm{cm}^{-2} \cdot \mathrm{d}^{-1}$ for the reproductive and maturity phases. Additionally, this researcher found that the response of the yields to light intensity is more evident in the reproductive phase of rice, followed by the grain-filling stage. This may explain to some extent why PD1 performed better in terms of grain yield; this sowing date had a higher number of days with values above $400 \mathrm{cal} \mathrm{cm}^{-2} \mathrm{~d}^{-1}$. Additionally, the accumulated solar radiation during each growth phase was higher compared with PD2 and PD3, respectively. These results corroborate the observations of other authors that explain the positive influence of high incident radiation levels on rice production in the final stages of the crop. Takai et al. (2006) and Restrepo and Garces (2013) also found a significant association between the amount of incident radiation in the reproductive and grain-filling stages and the percentage of filled spikelets. In addition, some studies have concluded that crops with high IPAR values can have a higher grain yield (Maddoni and Otegui, 1999; Ahmad, 2009). Similar observations were obtained in our experiment where PD1 had better IPAR values compared with the other sowing dates, causing a higher rice grain yield mainly in the 'F733' plants. 


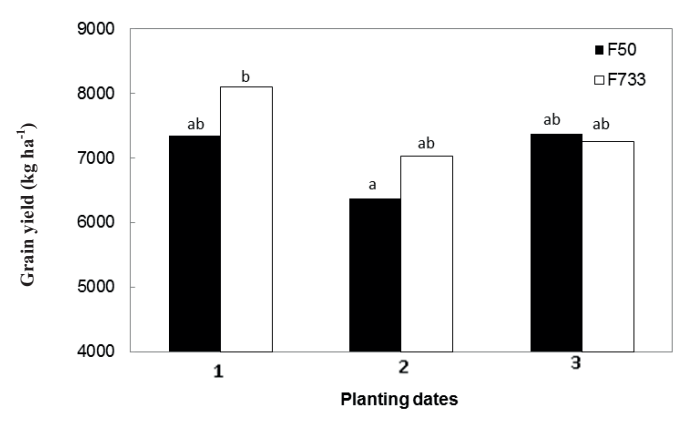

Figure 3. Grain yield of two cultivars of rice (Fedearroz 50 (F50) and Fedearroz 733 (F733)) for three different planting dates (Planting date 1 (January $1^{\text {st }}, 2012$ (PD1)), Planting date 2 (February 15 ${ }^{\text {th }}, 2012$ (PD2)) and Planting date 3 (April 1 ${ }^{\text {st }}, 2012$ (PD3)). Means with different letters represent statistically significant differences according to Tukey's test $(\mathrm{P} \leq 0.05)$.

Table 4. Determination of the degree of elasticity of the growth variables in relation to the incident solar energy.

\begin{tabular}{lll}
\hline Variable & Elasticity $(\beta)$ & Significance \\
\hline Biomass & 2.1919 & 0.0007 \\
Leaf area index & 1.4290 & 0.0001 \\
Crop growth rate & 0.8336 & 0.7480 \\
\hline
\end{tabular}

Table 5. Influence of planting date and cultivar on the Interception of Photosynthetic Active Radiation (IPAR) and Radiation use efficiency (RUE) in two cultivars of rice ('F50' vs. 'F733').

\begin{tabular}{ccc}
\hline Treatment & IPAR $\left(\mathrm{MJ} \cdot \mathrm{m}^{-2}\right)$ & RUE $\left(\mathrm{g} \cdot \mathrm{MJ}^{-1}\right)$ \\
\hline Planting Date (PD) & & \\
1 & $1068.11 \mathrm{a}^{1}$ & $1.56 \mathrm{a}$ \\
2 & $1025.99 \mathrm{~b}$ & $1.39 \mathrm{a}$ \\
3 & $993.90 \mathrm{c}$ & $1.49 \mathrm{a}$ \\
Significance & $* * * 2$ & $\mathrm{~ns}$ \\
Cultivar & & \\
F50 & $1028.73 \mathrm{a}$ & $1.39 \mathrm{~b}$ \\
F733 & $1029.94 \mathrm{a}$ & $1.58 \mathrm{a}$ \\
Significance & $\mathrm{ns}$ & $* * *$ \\
PD $\times$ Cultivar & $\mathrm{ns}$ & $\mathrm{ns}$ \\
$\mathrm{CV}$ (\%) & 0.38 & 10.44 \\
\hline
\end{tabular}

${ }^{1}$ Means with different letters represent statistically significant differences according to Tukey's test $(\mathrm{P} \leq 0.05)$.

${ }^{2}$ ANOVA: *** significantly different at the 0.001 probability level.

ns: not significant at 0.05 .

${ }^{3} \mathrm{CV}=$ Coefficient of Variation.
Regarding the influence of temperature on growth and grain yield in rice cultivation, some researchers have reported greater utility in studying the range of temperature during the day rather than analyzing the average temperature of the day. For example, the maximum and minimum temperature recorded on a given day may reach limiting values for different physiological processes of the plant, and this can be hidden only when the average daytime temperature is analyzed (Yin et al., 1996; Lobell, 2007). Therefore, in this study, the analysis of the maximum and minimum temperatures during the different evaluated planting dates is shown (Table 1). In general, the weather temperature data observed in this experiment helped eliminate daytime temperatures as a limiting factor because they did not exceed the critical range (above $35^{\circ} \mathrm{C}$ ). Daytime temperatures above this critical level may cause physiological disorders in rice plants (Cao et al., 2009; Restrepo-Diaz and Garces-Varon, 2013; Sanchez-Reinoso et al., 2014). As for the minimum temperatures, values slightly higher than the optimum values $\left(20-22^{\circ} \mathrm{C}\right)$ for rice cultivation were generally recorded during the three planting dates. This suggests that the minimum temperatures did not affect the grain yield due to the treatments of the different planting days.

After studying the growth parameters (LAI, CGR, and NAR), it was possible to see that for the three planting dates and for both cultivars, the maximum LAI was reached near the stage of flower development, with values between 6 and 7. This was similar to reports by other authors (San-oh et al., 2004). Moreover, when analyzing the influence of solar radiation and temperature using a correlation analysis and elasticity index on the growth parameters (Table 4 and 5), we found that solar radiation and temperature showed a significant positive influence on the dry matter production and LAI of rice. The elasticity values were higher for the climatic variable solar radiation, indicating that a change in solar energy has a greater impact on the LAI than a change in temperature. Other 
climatic variables such as relative humidity showed no significant correlation with biomass and LAI.

In terms of yield components, the number of panicles was lower in PD3 although there were no differences in the number of tillers (Figure 2 $\mathrm{A}$ and $\mathrm{B}$ ). In this sense, the number of productive tillers (those that can form panicles) depends on the environmental conditions during the primordium initiation and subsequent developmental stages (Fageria, 2007). Likewise, PD 3 also had a higher percentage of unfilled spikelets (Figure 3C). As mentioned previously, this high percentage of sterility is due to the incident radiation during the reproductive and maturity phases. On the other hand, the two cultivars evaluated ('F50' and 'F733') in the present study showed great susceptibility to conditions of low light availability in the reproductive stage, which caused a high percentage of sterile spikelets $(\geq 20 \%)$. A previous study also reported that these two Colombian rice cultivars had high susceptibility to low light intensities (Restrepo and Garcés, 2013). All of the above suggests that a decrease in yield compo- nents in PD3 may be due to the lower amount of solar radiation received during the reproductive phase compared with the other two dates, given that this sowing date showed an average of 410 cal $\cdot \mathrm{cm}^{-2} \cdot \mathrm{d}^{-1}$ in contrast with $432.9 \mathrm{cal} \cdot \mathrm{cm}^{-2} \cdot \mathrm{d}^{-1}$ of date 1. However, PD3 did not show differences in grain yield with respect to PD1 despite having fewer panicles and a higher percentage of empty spikelets. A plausible explanation for this behavior may be due to the fact that date 3 had higher dry matter accumulation in the vegetative stage and higher radiation in the maturity stage, providing a major source of assimilates and compensating for the drop in yield components.

These results allow us to conclude that the rice planting date in the main rice-producing areas in Colombia should be adjusted in such a way that their reproductive and grain-filling stages do not coincide with periods of low solar radiation ( $\leq$ $430 \mathrm{cal} \cdot \mathrm{cm}^{-2} \cdot \mathrm{d}^{-1}$ ), which can lower the grain yield. Moreover, these agronomic strategies can be used in plant breeding programs to characterize high-yield rice genotypes.

\title{
Resumen
}

\begin{abstract}
G. Garces-Varon y H. Restrepo-Diaz. 2015. Crecimiento y rendimiento de cultivares de arroz sembrados en diferentes fechas bajo condiciones tropicales. Cien. Inv. Agr. 42(2):217-226. Las plantas de arroz han demostrado susceptibilidad a condiciones de bajas o altas temperaturas durante las etapas reproductivas y de madurez. Dos cultivares de arroz: Fedearroz 50 (F50) y Fedearroz 733 (F733) se plantaron en tres fechas de siembra: 1 de enero (PD1), 15 de febrero (PD2) y 1 de abril (PD3), con el fin de tener diferentes condiciones climáticas durante las diferentes etapas de desarrollo del arroz. El experimento se desarrolló bajo un arreglo factorial. En cuanto a los datos del clima, la radiación solar fue el parámetro más fluctuante en las tres fechas de siembra, siendo PD1 el que tuvo un mayor número de días con valores $\geq 450 \mathrm{cal} \mathrm{cm}^{-2} \mathrm{~d}^{-1}$. Los componentes del rendimiento fueron influenciados por la época de siembra; PD3 mostró el menor número de macollas por unidad de superficie y el mayor porcentaje de espiguillas estériles. En cuanto a rendimiento de grano, PD1 y PD3 tuvieron el mejor comportamiento para las dos variedades 'F50' y 'F733'. Por otro lado, se alcanzó el índice de área óptimo de la hoja (7) aproximadamente a 85-90 días, para ambos cultivares en sus tres diferentes fechas de siembra, respectivamente. Del mismo modo, la radiación solar presentó una alta correlación con la producción de biomasa (materia seca) y el índice de área foliar. En conclusión, la fecha de siembra de arroz debe ajustarse de modo que la etapa reproductiva y llenado de grano no coinciden principalmente con periodos de baja radiación solar $\left(\leq 430 \mathrm{cal} \mathrm{cm}^{-2} \mathrm{~d}^{-1}\right)$, en condiciones tropicales.
\end{abstract}

Palabras clave: Arroz, hijuelos, índice de área foliar, fechas de siembra, porcentaje de espiguillas sin llenar, radiación solar, rendimiento de grano. 


\section{References}

Ahmad, A., S. Iqbal, S. Ahmad, T. Khaliq, W. Nasim, Z. Husnain, A. Hussain, M. Zia-Ul-Haq, and G. Hoogenboom. 2009. Seasonal growth, radiation interception, its conversion efficiency and biomass production of Oryza sativa L. under diverse agroenviroments in Pakistan. Pak. J. Bot. 41: 1241-1257.

Cao, Y.Y., H. Duan, L.N. Yang, Z.Q. Wang, L.J. Liu, and J.C. Yang. 2009. Effect of high temperature during heading and early filling on grain yield and physiological characteristics in Indica Rice. Acta Agronomica Sinica 35: 512-521.

Castilla, L.A., D. Pineda, J. Ospina, J. Echeverry, R. Perafan, G. Garcés, J. Sierra, and A. Díaz. 2010. Cambio climático y producción de arroz. Rev. Arroz 58: 4-11.

Dane-Fedearroz. 2012. Encuesta nacional de arroz mecanizado. II semestre de 2011. Available online at: http://www.dane.gov.co (Website accessed March 8, 2012).

Fageria, N.K. 2007. Yield physiology of rice. J. Plant. Nutr. 30: 843-879.

Fedearroz. 2012. Guía de trabajo-Adopción masiva de tecnología. Naxos Editores Bogotá D.C., Colombia. 27 pp.

Hunt, R. 1978. Plant growth analysis. Studies in Biology No. 96 Edward Arnold Limited, London. UK. p. 8-38.

Khalifa, A.A.B.A. 2009. Physiological evaluation of some hybrid rice varieties under different sowing dates. Aust. J. Crop Sci. 3: 178-183.

Lobell, D. 2007. Changes in diurnal temperature range and national cereal yields. Agr. Forest Meteorol. 145: 229-238.

Muchow, R.C., and P.S. Carberry. 1989. Environmental control of phenology and leaf growth in tropical adapted maize. Field Crops Res. 20: 221-236.

Restrepo, H., and G. Garces. 2013. Evaluation of low light intensity at three phenological stages in the agronomic and physiological responses of two rice (Oryza sativa L.) cultivars. Agronomia Colombiana 31: 55-60.

Restrepo-Díaz, H., and G. Garces-Varon. 2013. Response of rice plants to heat stress during initiation of panicle primordia or grain-filling phases. J Stress Physiol. Biochem. 9: 318-325.

Safdar, M.E., I.R. Noorka, A. Tanveer, S.A. Tariq, and S. Rauf. 2013. Growth and yield of advanced breeding lines of medium grain rice as influenced by different transplanting dates. J Anim. Plant Sci. 23: 227-231.

Sanchez-Reinoso, A.D., G. Garcés-Varon, and H. Restrepo-Díaz. 2014. Biochemical and physiological characterization of three rice cultivars under different daytime temperature conditions. Chil. J. Agr. Res. 74: 373-379.

San-oh, Y., Y. Mano, T. Ookawa, and T. Hirasawa. 2004. Comparison of dry matter production and associated characteristics between direct-sown and transplanted rice plants in a submerged paddy field and relationships to planting pattern. Field Crops Res. 87: 43-58.

Srivastava, G.C. 2011. Crop physiology. Biotech Books, New Delhi. 205 pp.

Takai, T., M. Yano, and T. Yamamoto. 2010. Canopy temperature on clear and cloudy days can be used to estimate varietal differences in stomatal conductance in rice. Field Crops Res. 115: 165 170.

Tsimba, R., G.O. Edmeadesb, J.P. Millnerc, and P.D. Kemp. 2013. The effect of planting date on maize grain yields and yield components. Field Crops Res. 150: 135-144.

Yin, X., M. Kropff, and R. Ellis. 1996. Rice flowering in response to diurnal temperature amplitude. Field Crops Res. 48: 1-9.

Yoshida, S. 1981. Fundamentals of rice crop science. International Rice Research Institute, Los Baños, Filipinas. 279 pp. 